Research Paper

\title{
Legal Protection for Vaccine Recipients Covid-19 in Indonesia
}

\section{Muhammad Mahendra Abdi ${ }^{1}$}

${ }^{1}$ Program Study of Law, Faculty of Humanities, University of Sari Mulia. Banjarmasin, Indonesia.

\section{Article History}

Received:

13.08.2021

Revised:

02.09.2021

\section{Accepted:}

14.09.2021

*Corresponding Author:

Muhammad Mahendra Abdi

Email:

mahendraabdi@gmail.com

This is an open access article, licensed under: $\mathrm{CC}-\mathrm{BY}-\mathrm{SA}$
Abstract: Regulation of the Minister of Health of the Republic of Indonesia Number 10 of 2021 concerning the Implementation of Vaccination in the Context of Combating the Corona Virus Disease 2019 (COVID-19) Pandemic, this Minister of Health Regulation is a government step in carrying out the legality of administering the COVID-19 vaccine because the spread of the COVID-19 virus is very fast. Occurs in humans, thus creating great concern for human life because it can lead to death. Therefore, the government took a response action by providing vaccinations for the people of Indonesia, the purpose of this vaccination is to overcome the high spread of COVID-19, the provision of the covid-19 vaccine given to the Indonesian people must also fulfill the proper rights for the recipients of the COVID-19 vaccine, so that when there is an impact on the administration of the Covid-19 vaccine, the government can handle it quickly. The problems in this paper are how is legal protection for people who receive the COVID-19 vaccine, the extent to which the government provides legal protection rights to people who receive the COVID-19 vaccine.

Keywords: COVID-19 Vaccination, Government, Legal Protection. 


\section{Introduction}

The world is currently being hit by a virus container, namely the presence of a new variant virus called the Severe Acute Respiratory Syndrome Coronavirus-2 (SARS CoV-2), and the disease is called Coronavirus disease 2019 (COVID-19). According to the World Health Organization (WHO), this virus originated from bat animals in the Chinese area, precisely in the Wuhan area, which was the first case of this type of Covid-19 virus.

The spread of this virus is very fast in humans, causing great concern for humanity, several highranking officials in certain countries have declared a lockdown in their countries such as the United States, Japan, Germany, South Korea, and other countries. The purpose of this lockdown is to anticipate the spike in the spread of the Covid-19 virus.

The rapid spread of the virus from human to human has resulted in almost the entire world being affected by this COVID-19 virus. The anticipation of the head of state doing a lockdown in his country is not without reason because this type of virus in addition to spreading very quickly also attacks human internal organs, namely breathing so that it can have an impact on death.

Since the first case in Wuhan, Covid-19 cases have been increasing every day. On March 12, 2020, WHO declared Covid-19 as a pandemic and nd as of June 16, 2021, there are 176,303,596 confirmed cases of COVID-19, and 3,820,026 deaths. Meanwhile, in Indonesia Covid-19 was first reported on March 2, 2020 a number of two cases. To date, as of June 16, 2021, there were 1,531,005 confirmed cases of COVID-19 in Indonesia, and 42,666 deaths.

\section{Literature Review}

The spread of the covid-19 virus from person to person is the root of the basic transmission, as a result the spread becomes more aggressive. Transmission of the spread of COVID-19 from symptomatic patients occurs through droplets that go from coughing or sneezing [1]. After transmission takes place, the virus enters the upper respiratory tract and then replicates in upper respiratory epithelial cells (performs its life cycle), after which it extends to the basic respiratory tract. In serious inflammation there is shedding of the virus from the respiratory tract and the virus may persist for some time in gastrointestinal cells after treatment. The incubation period is between 2-14 days from Covid-19, this Covid-19 virus has a high level of virulence (infects). However, the similarity of the initial symptoms of the Covid-19 virus with the symptoms of the common cold often causes people to ignore these symptoms. This causes a significant increase in cases [2].

Inflammation of Covid-19 can give rise to mild, moderate, or severe signs. Important clinical indications that arise are fever (temperature 38 degrees Celsius), phlegm stones and difficulty breathing. In addition, it can be accompanied by severe shortness of breath, fatigue, myalgia, gastrointestinal symptoms such as diarrhea and other respiratory symptoms. Half of the sufferers appear tight within one week. In severe cases of rapid and liberal worsening, such as ARDS, shock, septic, uncorrected metabolic acidosis and nosebleeds or coagulation system dysfunction within a few days.

In some patients the signs appear mild, let alone not accompanied by fever. The majority of patients have a good diagnosis, with a small proportion in critical condition let alone dead, so on clinical sentrom that can arise if contaminated [3].

a. No complications

This situation describes the lightest state, the indications that arise are in the form of an indefinite sign. The basic signs always arise such as fever, cough, and can be accompanied by sore throat, nasal congestion, malaise, headache, and muscle pain. It should be noted that in elderly patients and immunocompromised patients, the presentation of the indications is not typical or atypical, in addition, in some cases the symptoms are not accompanied by fever and the symptoms are relatively mild. In this situation, the patient has no signs of complications, including loss of body fluids, sepsis or shortness of breath.

b. Mild pneumonia

Important signs can arise such as fever, cough, and shortness of breath, but there are no signs of severe pneumonia. In children with mild pneumonia, it is indicated by coughing or shortness of breath.

c. Severe pneumonia, in elderly patients:

- Symptoms that arise include fever or caution, inflammation of the airways 
- Signs that arise are tachypnea (frequency of breath: 30x/minute), severe respiratory distress or acid saturation of the patient $<90 \%$ outside weather.

From the indications mentioned above, we know that the COVID-19 virus is very risky for people's survival. The steps in preventing the spread of the covid virus are also widely known, namely the Healthy and Clean Living Behavior (PHSB) is by cleaning hands regularly, sterilizing the surface of goods in an orderly manner, cleaning after walking, balancing with various fitness habits, increase the consumption of large nutritious dishes, exercise regularly, just take breaks, apply masks, and also do physical distancing.

Disobedience to the Healthy and Clean Living Behavior (PHSB) in the community causes this virus to spread its development and continues to increase day by day. Due to the increasing number of COVID-19 cases to date, the government has made a regulation. This regulation is to encourage or suppress the rate of development of COVID-19 in Indonesia. Namely, by the government providing a covid-19 antivirus vaccine for all people in Indonesia as stated in the Regulation of the Minister of Health of the Republic of Indonesia Number 10 of 2021 concerning the Implementation of Vaccination in the Context of Combating the Corona Virus Disease 2019 (COVID-19).

The government's efforts to make regulations on vaccination for the people of Indonesia encourage researchers to conduct studies on how to protect the law for people who receive the COVID-19 vaccine.

\section{Research Methods}

In this study, researchers used a normative study procedure. The procedure is an approach that is tried to examine the laws and regulations, norms, rules, legal concepts, as well as the opinions of legal experts in the bibliography or references that are directly tied to the subject of this research.

Research procedures used to examine cases as well as those stated in this research. The procedure in question is a Legislative Approach (Statue Aproach). The statutory approach is the activity of studying laws and regulations, principles, or legal norms that live in the community, especially those related to the problems studied, namely how to protect the law for residents who receive the COVID19 vaccine [4]. This research uses the Regulation of the Minister of Health of the Republic of Indonesia No. 10 of 2021 concerning the Implementation of Vaccination in the Context of Combating the 2019 Corona Virus Disease (COVID-19) Pandemic.

The author uses library research techniques to obtain data in his research. This technique is done by reading, studying and recording literature, notes, and various reports related to the problem to be solved that is in line with the discussion to be solved [5]. The results of the data obtained, then analyzed qualitatively in order to produce a conclusion.

\section{Discussion}

\subsection{Legal Protection}

Legal protection for Satjipti Raharjo is to provide support to the basic rights of people who are harmed by others and that protection is given to citizens so that they can enjoy all the rights granted by law [6]. There is also according to C. S. T Kansil Legal protection is a variety of legal remedies that must be submitted by law enforcement officers to provide a sense of comfort, both mentally and physically from obstacles and various dangers from any party [7].

Health development is one of the ordinary safety factors that must be realized by the authorities in accordance with the wishes of the Indonesian people as defined in the 1945 Constitution, namely to protect the entire Indonesian nation and the entire homeland of Indonesia and to promote public welfare, educate the nation's life and participate in implementing world order based on freedom, eternal peace and social justice. The implementation of health development includes health efforts and its resources, must be tried in a structured and sustainable way to achieve maximum results [8].

Legal protection describes part of an outline concept of the rule of law. In general, legal protection is divided into 2 rules, namely, protective legal protection and repressive legal protection. Legal protection protects is as a deterrent. Preventive legal protection is very meaningful for the actions of rulers based on freedom of action because with preventive legal protection, the authorities are encouraged to be careful in making decisions.

The form of preventive protection is contained in the legislation in order to prevent a violation from occurring and to provide limitations in carrying out obligations. Repressive legal protection 
serves to resolve disputes that have arisen on the surface as a result of a violation committed. This repressive legal protection is the last legal protection applied. The form is in the form of sanctions for certain violations that have been committed by someone.

The high number of COVID-19 cases in Indonesia urges the Government of the Republic of Indonesia to suppress the spread of this virus, one of the efforts made by the government in addition to advocating Healthy and Clean Living Behavior (PHSB), namely by vaccinating all Indonesian people. This is stated in the Regulation of the Minister of Health of the Republic of Indonesia Number 10 of 2021 concerning the Implementation of Vaccination in the Context of Combating the Corona Virus Disease 2019 (COVID-19) Pandemic.

\subsection{Priority for the COVID-19 Vaccination Group}

In article 1 point 3 of the Regulation of the Minister of Health Number 10 of 2021 concerning the Implementation of Vaccination in the Context of Combating the Corona Virus Disease 2019 (COVID19) Pandemic, it is the provision of Vaccines that are specifically given in the context of actively generating or increasing a person's immunity against a disease, so that if an when exposed to the disease will not get sick or only experience mild pain and not be a source of transmission

Article 1 paragraph 4 of the regulation of the minister of health Number 10 of 2021 Implementation of Vaccination in the Context of Combating the Corona Virus Disease 2019 (COVID19) pandemic reads "program vaccination is the implementation of vaccinations to the public whose funding is borne or charged to the government so that in this case the people who get government vaccinations are free of charge.

The groups of recipients of the COVID-19 vaccine as stated in Article 8 paragraph (3) of the Regulation of the Minister of Health Number 10 of 2021 Implementation of Vaccination in the Context of Combating the 2019 Corona Virus Disease (COVID-19) Pandemic, namely:

a) Health workers, assistants for health workers, and supporting staff working in Health Service Facilities;

b) Elderly people and public service personnel/officers

c) Vulnerable people from geospecial, social, and economic aspects; and

d) Other society.

Article 9 paragraph (1) of the Regulation of the Minister of Health Number 10 of 2021 concerning the Implementation of Vaccination in the Context of Combating the Corona Virus Disease 2019 (COVID-19) pandemic reads "Implementation of the COVID-19 Vaccination against priority groups of recipients of the COVID-19 Vaccine as referred to in Article 8 paragraph (3) is carried out through the Vaccination Program.

COVID-19, which attacks humans and has become a pandemic category, has prompted the government to make efforts to protect the health of the people of Indonesia. The protection of health in Indonesia has been regulated in Article $28 \mathrm{H}$ paragraph (1) of the 1945 Constitution of the Republic of Indonesia which states that everyone has the right to live in physical and spiritual prosperity, to have a place to live, and to have a good and healthy living environment and have the right to receive health services. According to Levey Loomba, health services are efforts made by an organization either individually or jointly to maintain and improve health, prevent and cure disease and restore individuals, groups and or communities [9].

Apart from the 1945 Constitution of the Republic of Indonesia, the government specifically makes laws for health, namely Law Number 23 of 1992 concerning Health, and has been updated with Law Number 36 of 2009 concerning Health. This law places great emphasis on health protection for Indonesian citizens.

\subsection{Right to Health}

Health is a human right which is essentially influenced by many factors, especially the environment and behavior. Health is not the only thing in human life. But a person's health shows the quality of life in his environment. Health according to the World Health Organization (WHO) is a state of complete physical, mental and social well-being and not only the absence of disease. This definition of healthy according to WHO implies that health is not a disease context but also looks at health in the context of the environment. 
According to article 1 paragraph 1 of Law 36 of 2009 concerning health, it reads "Health is a healthy state, both physically, mentally, spiritually and socially that allows everyone to live socially and economically productive. In general, healthy can be interpreted as a life that must be creative and productive. Health, which is a human right, is included in one of the elements of welfare that must be realized in the form of the ideals and goals of the Indonesian nation. Health cannot be replaced with money because to ensure one's health, one's wealth may run out due to the disease he is suffering from.

Health is a right and an investment, and all citizens, especially Indonesia, have the right to health. Article $28 \mathrm{H}$ paragraph (1) of the Constitution of the Republic of Indonesia and also in Law Number 36 of 2009 concerning Health stipulates that health is a fundamental right of every citizen. Therefore, every individual, family and community has the right to obtain protection for their health and the state is responsible for regulating the fulfillment of the right to a healthy life for its inhabitants regardless of their rank or caste.

Health law according to Noorsyamsul Jastan in his book entitled health law defines that health law is a series of health that regulates medical services and medical facilities. Medical service is an institutionalized health service effort, based on social functions in the field of individual health services for individuals and families. Meanwhile, the medical facilities include hospitals, specialist clinics, treatment centers, polyclinics, and other facilities that have been determined by the minister of health [10].

Talking about health problems, there are two aspects of health, namely aspects of health efforts and aspects and aspects of health resources. The aspect of health resources consists of health targets, including hospitals, health centers, medical centers, doctor's practices, and health workers such as doctors, nurses, pharmacists. One aspect of health efforts is health maintenance. Individual health maintenance is known as medical maintenance [11].

\subsection{Patient Rights Vaccination Coronavirus Disease 2019}

Health development is directed at increasing the degree of health, which has great meaning for the development and development of human resources and as capital for the implementation of national development which is basically complete human development and the development of the entire Indonesian people which must be supported by the government in the health of all Indonesian people by facilitating all supporters of the utilization of health, reflecting on Article 14 paragraphs (1) and (2) of Law Number 36 of 2009 concerning health which reads

(1) The government is responsible for planning, regulating, organizing, fostering, and supervising the implementation of health efforts that are equitable and affordable by the community.

(2) The responsibility of the Government as referred to in paragraph is devoted to public services.

Referring to the Regulation of the Minister of Health Number 10 of 2021 Implementation of Vaccination in the Context of Combating the Corona Virus Disease 2019 (COVID-19) Pandemic is the first step or effort from the Indonesian government in terms of regulations to vaccinate the Indonesian people. The protection of the Indonesian people who are free from this pandemic is a right for the Indonesian people. People who receive health services can be called patients or consumers in the field of health services.

Janus sidabalok in his book on Consumer Protection Law in Indonesia states that there are three kinds of rights based on the source of fulfillment, namely [12]:

a) Human rights because of their nature, namely the rights we get when we are born, such as the right to live and the right to breathe. This right cannot be contested by the state and even the state is obliged to guarantee its fulfillment.

b) Rights born from law, namely rights granted by the state to its citizens. This right is also referred to as a legal right, for example the right to vote in elections.

c) Rights born from contractual relationships, these rights are based on agreements/contracts between one person and another. For example in the event of buying and selling. The buyer's right is to receive the goods, while the seller's right is to receive money.

The field of health services has very distinctive characteristics that are different from other services or products, namely consumer ignorance. 
Based on the dimensions of the quality of health services, the expectations of patients as consumers of medical services include:

a) Delivering the promised service immediately and satisfactorily

b) Assist and provide services responsively without discriminating elements of SARA (ethnicity, religion, race and between groups)

c) Guaranteed security, safety, and comfort

d) Good communication and understanding patient needs

The former president of the United States, John F. Kennedy. Has put forward four basic rights of consumers, namely [13]:

a) The right to safe products.

b) The right to be informed abaut products.

c) The right to definite choices in selecting products.

d) The right to be heard regarding consumer products.

In addition, specifically regarding consumer rights, it is regulated in Article 4 of Law Number 8 of 1999 concerning Consumer Protection, consumers have rights including the right to comfort, security, and safety in consuming goods and/or services [14]

a) The right to choose goods and/or services and to obtain such goods and/or services in accordance with the exchange rate and the promised conditions and guarantees;

b) the right to correct, clear and honest information regarding the conditions and guarantees of goods and/or services;

c) The right to have their opinions and complaints heard on the goods and/or services used;

d) The right to obtain proper advocacy, protection, and efforts to resolve consumer protection disputes;

e) The right to receive consumer guidance and education;

f) The right to be treated or served correctly and honestly and not discriminatory;

g) The right to obtain compensation, compensation and/or replacement, if the goods and/or services received are not in accordance with the agreement or not properly;

h) Rights regulated in the provisions of other laws and regulations.

From the nine items described in the law, it is clear that consumer rights, comfort, security and safety are the most basic and essential in consumer protection. Goods or services that are not comfortable or harmful to consumers are strongly discouraged or can be said to not be circulated in the community. Therefore, service and/or goods providers must have clear, honest and correct information regarding the goods and/or services provided to consumers.

The patient's right as a consumer is the right to be heard and to get compensation if the service obtained is not as it should be. The rights of patients as consumers of medical services that have been determined in Law Number 36 Year 2009 concerning Health are [15]:

- Article 4 "everyone has the right to health"

- Article 5 paragraph:

(1) "Everyone has the same rights in obtaining access to resources in the health sector".

(2) "Everyone has the right to obtain safe, quality, and affordable health services"

(3) "Everyone has the right to independently and responsibly determine the health services needed for himself".

- Article 6 "Everyone has the right to a healthy environment for the achievement of health degrees".

- Article 7 "Everyone has the right to obtain balanced and responsible health information and education".

- Article 8 "Everyone has the right to obtain information about his/her health data including actions and treatments that have been or will be received from health workers".

- Article 58 "everyone has the right to claim compensation for a person, health worker, and/or health provider who causes losses due to errors or omissions in the health services he receives" 
In addition, patients are also obliged to provide correct information to health workers about their health, comply with the recommendations given by health workers in the context of diagnosis, treatment, or treatment.

In the event of a COVID-19 vaccination organized by the Indonesian government which has determined the target who gets vaccinated in accordance with Article 8 paragraph (3) of the Regulation of the Minister of Health Number 10 of 2021 Implementation of Vaccination in the Context of Combating the Corona Virus Disease 2019 (COVID-19) Pandemic, then protection The law for the recipient of this vaccination has also been stated in Article 37 paragraph [16]:

(1) "In the event that there is a case of Post Vaccination Adverse Events that is affected by the COVID19 Vaccine product based on the results of the causality study as referred to in Article 35 paragraph (3), and the case causes disability or death, compensation will be given by the Government".

(2) "The form of compensation as referred to in paragraph (1) is in the form of disability compensation or death compensation".

From these provisions, it appears that the rights and obligations of business actors are reciprocal with the rights and obligations of patients as consumers. This means that the rights of consumers as patients are obligations that must be fulfilled by business actors (government). Likewise, the patient's obligation as a consumer is a right that will be accepted by business actors (government).

From the losses suffered by the patient, in this case it may not be much or it could be that the loss is not good for the patient. A person can be asked for legal responsibility (liable). If someone makes an omission/error and the error/omission causes a loss to the patient in medical services, the patient in this case can claim compensation for the error or negligence he suffered as a result of the health service.

\section{Conclusion}

The rights of consumers in receiving goods and/or services as regulated in Law Number 8 of 1999 concerning consumer protection and also the rights of patients as regulated in Law Number 36 of 2009 concerning health and also the right to receive COVID-19 vaccinations which are regulated in Regulations Minister of Health Number 10 of 2021 Implementation of Vaccination in the Context of Combating the Corona Virus Disease 2019 (COVID-19) Pandemic, it can be concluded that every person who receives goods and/or service products has the right to correct and complete information about the condition of the goods and/or services received or circumstances about him.

Consumers or patients have the right to get services that are appropriate for their health, besides that patients as consumers also have an obligation to notify their condition to health workers in order to get maximum service for protection and/or legal certainty for themselves. In consumer protection there is also the principle of consumer security and safety, that consumer protection provides security and safety guarantees to consumers in the use, use, and utilization of goods and/or services consumed or used by themselves.

The granting of the right to compensation as a result of the COVID-19 vaccination is an effort to provide protection for everyone for any consequences that arise, both physical and non-physical due to the error or negligence of the health officer or the organizing body. This protection is very important because the result of negligence or error may cause death or cause disability.

Legal protection for patients is stated in Law Number 36 of 2009 concerning health in general, because patients are consumers of services, Law Number 8 of 1999 concerning Consumer Protection also applies. However, for cases due to COVID-19 vaccination, it is specifically regulated in the Minister of Health Regulation Number 10 of 2021 on the Implementation of Vaccination in the Context of Combating the Corona Virus Disease 2019 (COVID-19) Pandemic, in Article 35 paragraph (3) Permenkes No. 10 of 2021 reads that "In the event that the results of a causality study by the National Committee for the Assessment and Management of Adverse Events after Immunization as referred to in paragraph (2) there are allegations of being influenced by the COVID19 Vaccine product, the Food and Drug Supervisory Agency shall conduct sampling and testing in accordance with the provisions of laws and regulations". Furthermore, in Article 40 of the Minister of Health No. 10 of 2021 reads "Stipulations regarding the amount of disability compensation or death compensation shall be determined by the Minister after obtaining approval from the Minister of Finance". 
In granting patient rights, the government should be ready in all kinds of rules regarding compensation given to residents affected by the COVID-19 vaccination. Because until now the government has not made a regulation on the handling of compensation. In handling this compensation, the government should provide the best rights for victims of COVID-19 vaccination.

\section{References}

[1] Y. Han, and H. Yang, "The transmission and diagnosis of 2019 novel coronavirus infection disease (COVID-19): A Chinese perspective.” Journal of Medical Virology, vol. 92, no. 6, pp. 639-644. 2020. [Online]. Available: https://doi.org/10.1002/jmv.25749. [Accessed: Sept. 10, 2020].

[2] N. Hastuti, and S. N. Djanah, "Literature Review Study: Transmission and Prevention of the Spread of Covid-19," Journal of Public Health, vol. 7, no. 2, pp. 70-79, 2020. [Online]. Available: https://ojs.uniska-bjm.ac.id/index.php/ANN/article/view/2984. [Accessed: Sept. 10, 2020].

[3] A. Susilo, C. M Rumende, dkk, "Coronavirus Disease 2019: Recent Literature Review," Indonesian Journal of Internal Medicine, vol. 7, no. 1, pp. 45, 2020. [Online]. Available: https://doi.org/10.7454/jpdi.v7i1.415. [Accessed: Sept. 10, 2020].

[4] P. Marzuki, Legal Research, Jakarta: Prenada Group, 2017.

[5] M. Sari, "Natural Science," Journal of Science Research and Science Education, vol. 6, no. 1, pp. 41-53, 2020.

[6] S. Rahardjo, Legal Studies, Jakarta: PT. Image of Aditya Bakti, 2020.

[7] C. S. T. Kansil, Introduction to Indonesian Law and Legal Administration, Jakarta: Balai Pustaka, 1989.

[8] Z. Asyhadie, Legal Aspects of Health in Indonesia. Jakarta: PT Raja Grafindo Persada, 2017.

[9] T. Radito, "Analysis of the Effect of Service Quality and Health Facilities on Patient Satisfaction at the Health Center," Journal of Management Science, vol. 11, no. 2, pp. 1-25, 2014. [Online]. Available: https://doi.org/10.21831/jim.v11i2.11753. [Accessed: Sept. 10, 2020].

[10] N. Jastan, and M. Riyadi, Health Law. Banjarmasin: YPTIH Sultan Adam Press, 2010.

[11] M. Riyadi, Medical Malpractice in Therapeutic Contracts, Banjarmasin: Salarsar press, 2010.

[12] J. Sidabalok, Consumer Protection Law in Indonesia. Liability According to Civil Law. Jakarta: Raja Grafindo Persada, 2006.

[13] G. Widjaja, and A. Yani, Law on Consumer Protection, Jakarta: Public Library Gramedia, 2003.

[14] Sekretariat Negara, "Undang-Undang Republik Indonesia No. 8 Tahun 1999," 1999 [Online]. Available https://jdih.setneg.go.id/Produk [Accessed: Sept. 10 ,2020].

[15] Sekretariat Negara, "Undang-Undang Republik Indonesia No. 36 Tahun 2009," 2009 [Online]. Available https://jdih.setneg.go.id/Produk [Accessed: Sept. 10, 2020].

[16] Kementerian Kesehatan, "Peraturan Menteri Kesehatan Republik Indonesia No.10 Tahun 2021," 2021 [Online]. Available https://jdih.kemkes.go.id/dokumen/peraturan?page=2\&perpage $=5$ [Accessed: June. 10,2020$]$. 